\title{
Prototype Analysis Of Elemantary School Teacher Of Kecamatan Pariaman Tengah Kota Pariaman
}

\author{
Rifma \\ Department of Educational Management \\ Universitas Negeri Padang \\ Padang, Indonesia \\ Corresponding e-mail: Rifmar34@gmail.com
}

\begin{abstract}
Prototype/category of teachers is a picture of the condition of teachers seen from the commitment and abstraction abilities in performing the task. Prototype/category of teachers should be known by the principal and supervisors in order to carry out supervision. Description of the prototype/category of teachers is used as the basis for consideration for principals and supervisors in selecting and adjusting supervision services to teachers, so that supervision is carried out more effectively. This study aims to obtain data and description of the prototype/category of teachers in SD N Kecamatan Pariaman Tengah Kota Pariaman. The study population is all teachers of SD N Kecamatan Pariaman Tengah Kota Pariaman, amounting to 186 people spread over 20 schools. The sample size is $25 \%$ of the population or 47 people. Determination of sample is done by using technique of Proportional Stratified Random Sampling at each cluster. Data collected using a questionnaire that has been tested and validated by an expert. Data were analyzed by using the Mean (average) formula. The results describe; (a) Teacher's commitment in performing tasks is high with an average score of 3.97, (b) Ability of teacher abstraction is in medium category with average score 3.54, and (c) Based on the description of commitment and abstraction ability of the teacher It was found that in general teachers in Kecamatan Pariaman Tengah Elementary School are in quadrant II called unfocus teachers.
\end{abstract}

Keyward: Analysis, prototype, analytic, unfocus

\section{INTRODUCTION}

The quality of learning has always been an interesting topic to talk about. This is because the quality of learning will color the achievement of the quality of education at every level of educational unit. Good learning becomes the overall determinant of school quality. If learning is of good quality, it is almost certain that quality schools can be realized. The results of Kamla's study quoted by Suhardan (2010: 70) indicate that there are three important components that are very influential in the successful teaching process, namely teacher personality, teacher professionalism, and the background of skills he mastered based on previous education. It is also affirmed in Law No. 14 of 2005 on Teachers and Lecturers that teachers are required to have four competencies: 1) pedagogic competence, 1) personality competence, 3 ) social competence, and 4) rofesional competence. The form of ownership of such competence can be seen from the implementation of teacher duties. The results of the teacher competency test (SME) of SD that will be certified implemented in West Sumatra 2015 obtained an average score of 47.86 and is below the national average.

Optimizing the implementation of teacher tasks requires commitment and abstraction abilities from teachers. Pidarta (2009: 144) states commitment is an attitude that is accompanied by the realization of that attitude in everyday life, including in carrying out job duties. Abstraction abilities are expressed as the ability of a person to imagine something that has been observed. The ability of a person's abstraction is seen as representing a person's level of general ability. Thus the level of abstraction abilities in teachers is seen as a reflection of the level of general ability of the teacher. Citing the opinion of Glickman (1981) in Muslim (2009: 82) states abstract ability of teachers are classified into three levels namely low (low), moderate (moderate), and high (high). The classification is based on the teacher's response when faced with problems in performing his duties.

In reality not all teachers are able to perform their duties and functions to the fullest. Rifma (2013: 12) found several problems of teachers in managing the learning that is: (1) In general, teachers observed have not compiled the program, syllabus or learning implementation plan (RPP) before doing the learning. If there are teachers who have syllabus and lesson plans, they are not used as guidance in teaching but for teachers' administrative completeness; (2) In general implementation of learning method is less varied, not using media / props, teaching skill less mastered, and less give concrete examples in explaining the subject matter; (3) underprivileged teachers prepare their own questions to be used, do not have problem banks, very rarely do problem 
analysis, and often take questions from student package books.

Given the teacher is a central element in achieving the quality of learning that will ultimately lead to improving the quality of education, the teacher coaching program becomes an agenda that absolutely carried out seriously and sustainably. Suhardan (2010: 87) mentions that the ability to teach teachers need to get coaching so that they have the authority to teach in accordance with the demands of the times. Merchants and Idrus (2009: 85) describe any efforts to improve the quality of education such as curriculum changes, the development of teaching methods, the provision of facilities and infrastructure will be meaningful when involving teachers.

However, the problem arises, there is still a lot of guidance done by the principal and supervisor has not been able to touch the point of problems and the needs of teachers to the coaching itself. The results of Rifma's research (2013: 304-305) show that principals and supervisors have not provided guidance on teacher competence as a whole. Most of which are examined or seen by the principal is the administration of teachers and the use of media in learning. While the ability to implement interactive learning and the ability to carry out the evaluation has not been the target of supervision by the principal. Wahidah (2015: 129) found that the teacher's teaching-learning program developed by the headmaster was not in accordance with the expected phases. In the supervision program has not included the target and schedule regarding the implementation of the guidance. In addition, Merukh (2016) also found that the principal's supervisory goals were not in accordance with the needs of teachers.

One of the supervisory competencies required in this case is to know the prototype of the teacher so that it can supervise with various approaches, either directly, indirectly, or collaboratively (Darsono, 2016: 338). In parallel, Purnawanti et al (2016: 162) states that grouping on the basis of teachers' ability will facilitate the provision of supervision services to teachers. With relatively similar characteristics will get treatment and handling relatively the same. The teacher grouping based on teacher abstraction and commitment by Glikman (in Muslim, 2009: 84) is called the prototype or teacher category.

Referring to the phenomenon, the authors are interested and motivated to propose an effort in order to assist the implementation of the principal's duties and supervisors as supervisors in schools by analyzing the prototype / category of elementary school teachers through a study. This research will try to help principals and supervisors in mapping the prototype / teacher category to be fostered. Mapping teacher category is done through an analysis of two dimensions namely, the level of commitment and level of teacher abstraction in performing the task.

\section{METHODS}

This research includes descriptive type of research that will describe, reveal and interpret data related to prototype / teacher category seen from commitment and abstract ability in performing task. Based on the data and information teachers can be classified according to the level of teacher prototype consisting of quadrant I (Dropout), quadrant II (Unfocus), quadrant III (Analytic), quadrant IV (Professional). The research was conducted in elementary school of Kecamatan Pariaman Tengah Kota Pariaman.

The population of this research is elementary school teacher of Kecamatan Pariaman Tengah Kota Pariaman as many as 186 teachers spread over 20 elementary schools in Kecamatan Pariaman Tengah Kota Pariaman. The sample is determined $25 \%$ of the population that is 47 people and the determination of the sample using Proportional Startified Random Sampling technique. The data collection tool uses a questionnaire in the form of Likert scale and has tested its validity and reliability. In addition, this questionnaire was also validated by 2 experts from the field of expertise in Psychology and Guidance and Counseling. Data were analyzed by using simple statistic ie calculate Mean (mean).

\section{RESULT AND DISCUSSION}

In this section described the results of research related to commitment and abstraction ability of teachers in performing the task. The teacher's commitment to this research is seen from several aspects: (a) Caring for the task, (b) Loyalty, (c) Responsibility, (d) Self-discipline, (e) Response to change, and (f) Self-Ability of abstraction of teacher in this research seen from two aspect that is ability in solving problem and ability in performing task.

\subsection{Teacher's Commitment in Implementing Task}

The results showed that in general, teachers already have a high commitment in performing tasks with an average score of 3.95. Among them there are 2 people $(4.25 \%)$ teachers who have shown a very high commitment with an average score of 4.70 and 4.85. In addition, $3(6.4 \%)$ teachers were still committed with an average score of 3.1, 3.3, and 3.4. This commitment is a key factor affecting teachers in work. Caladarci (1992) defines commitment to teachers as "Teachers' psychological attachment to the teaching profession". Commitment to the teacher will be seen from the behavior of the constants he or she raises in working at the same time describing his philosophy towards education. Furthermore Firestone \& Rosenblum (1988) mentions "commitment result from the job satisfaction". In this case the highest 
level of job satisfaction will affect teacher commitment.

When viewed from the aspects of commitment itself, it was found that in general the teacher in carrying out the task has been very disciplin with an average score of 4.72 , but still found 7 people $(14.89 \%)$ teachers discipline is still in the high category. Thus the majority of teachers have commitments related to the time and rules/regulations that have been established in the school which is implied from his obedience in carrying out the task. Discipline behavior is the awareness and willingness of a person to comply with all organizational rules and social norms that apply (Hasibuan, 2012: 193). In connection with this Sutrisno (2009: 86) suggests that the discipline shows a condition or attitude of respect that is in the teacher to the rules and regulations of the school.

Furthermore, the teacher's concern in performing tasks is high with an average score of 4.03. Found 5 people among them $(10.64 \%)$ already have a very high awareness, but there are still 6 people $(12.77 \%)$ teachers whose concern in carrying out the task is still lacking. Teacher's concern in carrying out tasks related to the effort made to provide services as much as possible to learners learners. As stated by Mart (2013) that "committed teachers are concerned with the development of their students and they profoundly struggle how to keep students learning". By demonstrating a high commitment to learning, this can be an important factor in motivating learners. In this case Mart (2013) mentions "Motivation, which is one of the leading factors of this educational achievement, ca be easily maintained by commitment". High teacher awareness in carrying out the tasks can have a significant impact on the success of learning learners. Singh \& Billinnsgley affirmed the "low level of teachers 'commitment reduces students' achievement". Teachers committed to learning do all the work they can to develop the potential of learners and learning situations to the fullest.

Teacher loyalty is also in the high category with an average score of 3.64 . Two teachers $(4.25 \%)$ have high loyalty, but on the other hand found 20 people $(42.55 \%)$ teachers who have loyalty in the category enough. Loyalty in this case is the attitude of teachers who are willing to give more attention in the form of energy, time, thought, and material to the school as an organization and community in it. Loyalty is associated with teacher commitment to school. Mowday et al. (1979) defined "commitment to school as teachers' belief and acceptance of the goals and values of the school; Teachers' efforts for adopting those goals and values, and their strong desire to keep up involvement in the school. "Teacher's loyalty to the school will arise if the teacher is committed to becoming part of the school (morale) and engaging in various school activities. As stated by Glickman (1993) that "Commitment to the institution in Education manifests itself in identifying with the school, feeling like part of the school, and loyalty to the school". Indicators that show teacher loyalty are not only related to school development programs. Calep (2000) explains "Variables that determine the level of teachers' commitment to school; Interaction between teachers, relationship between teacher and student, the quality of the work is done by teachers and a compatible working environment between teacher and school administration ". Providing learning services outside of learning hours to learners, providing collegial assistance in the context of improving learning, accepting additional assignments from the principal, and engaging in various school programs is evidence of a teacher's loyalty. Oberholster \& Taylor (1999) affirm "point out that teachers with low levels of commitment are less loyal to the organization". Thus teachers with high loyalty to the school are willing to work beyond their responsibilities as teachers.

The research data also shows that teacher responsibilities are in the high category with an average score of 4.1 . Only 9 persons $(19.15 \%)$ of teachers who have very high responsibility, and found 4 persons $(8.51 \%)$ who still have responsibility on the category enough. Teaching profession is responsible for carrying out the tasks inherent in the profession of a teacher, especially working on various ways to create the best learning process. On the other hand, teachers become part of the school community who is responsible for taking a role in seeking the development of the school as an organization. As stated by Raymond B. Fox (1964) "the committed teacher recognizes his professional responsibilities to students, colleagues, administrators, parents, and community". So the level of responsibility of teachers in carrying out these tasks become an indicator of teacher professionalism as an educator.

Furthermore, teachers' responsiveness to change is also in the high category with an average score of 3.8. Two teachers $(4.24 \%)$ were already very responsive to the changes, but there were still 16 (34.04\%) teachers who still had responsibilities in the sufficient category. Response to change is the attitude of teachers who are committed to always make improvements to the learning process. Mart (2013) states "a committed teacher always makes every effort to advance students' professional competence by providing them a quality learning environment". Improvements to teaching and learning situations are impossible if teachers are not sensitive to developments and innovations in education especially in learning practices. These developments may include new innovations in approaches, models, strategies, media, including curriculum changes. Teachers who are responsive to change are teachers who actively pick up information and new sciences, not teachers who are just waiting for information and knowledge to come by 
themselves or even forced others to have. In this case the teacher has a positive view of the new innovations in education characterized by an attitude of openness and willingness to continue to learn and practice new things in the learning process it does.

\subsection{Abstraction of Teacher Ability}

Ability of abstraction of teacher in this research seen from two aspect that is ability in solving problem and ability in performing task. The result of research that abstraction ability of teacher is enough category with average score 3.54. In detail found 19 people $(40.43 \%)$ abstraction abilities are in the high category and the remaining 28 people $(59.57 \%)$ are in enough categories. Glickman in Muslim (2009) mentions the characteristics of teachers who have moderate abstractions: (a) can fix the problem, (b) be able to think of one or two possible answers to the problem, and (c) experience mental disorder through a comprehensive plan.

When viewed from the aspect of the abstraction ability of teachers, it was found that the ability of teachers in solving the problem is in enough category with an average score of 3.55 . Only 1 person $(2.13 \%)$ teachers who have problem solving skills are very high, 24 people $(51.06 \%)$ are in the high category, and the remaining $22(46.81 \%)$ are in enough category. Teacher ability to perform the task, generally in the category enough with an average score of 3.53 . Found 22 people $(48,94 \%)$ teachers have the ability to perform high tasks, and the remaining 25 people $(51.06 \%)$ have sufficient ability.

Pidarta (2009: 144) mentions abstraction as a person's ability to imagine something that has been observed. Ability of a teacher's abstraction is seen as representing the level of general ability of the teacher. In other words, teacher abstraction is the ability of teachers to assemble and organize various knowledge, experience, and skills in solving problems related to the implementation of the task as a teacher. Abstraction in this research is related to teacher's cognitive ability. Spincer \& Signe (1993) states "the cognitive competencies function as an intellectual version of initiative: the tasks, problems, opportunities, or body of knowlage". All that can be reflected from aspects of individual maturity in interacting with others and their work. In other words a teacher's cognitive ability will determine the level of effectiveness of his work.

\subsection{Teacher Prototype Analysis}

The results showed that teachers in Pariaman Tengah sub-district consist of two categories, namely unfocus teacher category and analytic teacher category. From the data it can be seen that there are 21 people $(44.68 \%)$ which included the category of teacher analytic and 26 people $(55.32 \%)$ which belongs to unfocus teacher category. The results show that teachers in Pariaman Tengah sub-district have a lot of high commitment in performing their tasks, but less in abstraction ability. Thus it can be concluded that there are still many teachers in Kecamatan Pariaman Tengah which belong to unfocus teacher category.

Adopting the Glickman paradigm that categorizes teachers into 4 quadrants based on the two basic abilities of teachers are abstract thinking and commitment in performing the task. Quadrant I describes a teacher who has low commitment and low abstraction level. The teacher in quadrant $\mathrm{I}$ is called dropout teacher or less qualified. Characteristics that characterize teachers in this quadrant are: (a) Teachers are functioning at very low developmental levels. (B) Teacher do not have awareness, knowlage or inclination to act on an issue ... (Glickman, 2005). Can be summarized by the teacher in this quadrant: (a) perform tasks only to a minimum, (b) have little motivation to increase competence, (c) he can not think of improvements to be done, (d) satisfied performing routine tasks performed from day to day. In this quadrant teachers can be fostered by supervision approach directive control behaviors.

Quadrant II is unfocused worker. Teachers in this quadrant have high commitment but low abstraction level. Characteristics, among others, have a high enthusiasm, energetic and full of will. But the ability of the teacher is less in solving the problem and rarely do something realistically. Further, to cite the opinion of Glickman (2004) in this category, teachers are fostered by directive informational behaviors approach because they show the following characteristics: (a) Functioning at fairly low developmental level. (B) Teacher does not posses the knowlage about an issue that the supervisor clearly possesses. (C) Teacher feel confuse, inexperienced, or is at loss for what to do.

Qudrant III is an analytical observer. Teachers in this quadra have low level of commitment but high abstract thinking ability. Analytical Teachers are able to think comprehensively and systematically to a problem. As defined by Spencer \& Signe (1993) that "Analitycal thingking is understanding a situation by breaking it into a casual way." Characteristics include: having a high intelligence, able to give a good idea of what can be done in the classroom and even the school as a whole. Be able to discuss issues and think of successful steps for implementing those ideas. But it does not want to provide the time, effort, and attention it takes to do the plan. So in this quadrant the proper coaching for teachers is to use Collaborative behaviors (Glickman, 2005).

The last quadrant IV is a highly committed professional teacher and the level of abstraction is also high. The teacher in this quadrant is the type of thinker and executive. Characteristics, willing to continually improve their abilities, learners, and fellow teachers. Glickman (2005) also explained 
teachers in this quadrant have characteristics: (a) Teachers are fungtioning at high developnmental levels. (B) Teacher possess most of the knowlage and expertise about the issue. (C) Teacher has full responsibility for carrying out the decision. (E) Teacher is committed to solving the problem. And teachers in this quadrant of coaching can be done with nondirective behaviors approach.

\section{CONCLUSION}

\subsection{Conclusion}

Based on the above research results can be put forward some conclusions as follows:

1. Teacher's commitment in performing tasks is already high. This can be seen primarily through the very high teacher discipline in performing the task.

2. Ability of abstraction of teacher in general still in medium category, good ability in solving problem and ability in carrying out duty.

3. Viewed from the commitment and abstraction abilities in general, elementary school teachers in Kabupaten Pariaman Tengah Kota Pariaman still tend to be in the category of unfocus teachers.

\subsection{Suggestion}

1. Elementary school teachers in Kabupaten Pariaman Tengah Kota Pariaman have high commitment, but abstraction ability is still low. It is therefore advisable to the principal and supervisor to develop a supervisory program that is more directed to the coaching and improvement of teachers abstraction abilities.

2. Head of Education Office of Youth and Sports Kota Pariaman expected to develop a teacher coaching program in the form of the provision of reading material facilities that can improve teacher insight, especially related to the teacher as a teacher.

3. Further research can be directed to research on teacher-based guidance category.

\section{REFERENCES}

[1] Celep, C. (2000). Teachers' Organizational Commitment In Educational Organizations. Trakya University. Edirne,TURKEY. National Forum of Teacher Education Journal, 1 (10E), (3). ERIC NO: ED452179.

[2] Cohen, A. (2003). Multiple commitments in the workplace: An integrative approach.Mahwah, NJ: Erlbaum.
[3] Coladarci, T. (1992). Teachers' Sense of Efficacy and Commitment to Teaching. The Journal of Experimental Education, 60 (4), 323-337.

[4] Danim, Sudarwan. (2010). Profesionalisasi dan Etika Profesi Guru. Bandung: Alfabeta.

[5] Darsono. 2016. Implementasi Pendekatan Direktif, Non Direktif, dan Kolaboratif dalam Supervise Pendidikan Islam: Studi Kasus di MAN Trenggalek. Jurnal Ta'allum, Volume 04, Nomor 02. Novembar 2016. Halaman 335-357.

[6] Firestone, W. A., \& Rosenblum, S. (1988). Building commitment in urban high schools. Educational Evaluation and Policy Analysis, 10, 285-299.

[7] Glickman, C. (1993). Renewing America's School: A Guide for School-based Action. Jossey-Bass, San Fransisco,CA

[8] Glickman \& Gordon. (2005). Supervision and Instructional Leadership: A Developmental Approach (Sixth Edition). USA: Pearson Education, Inc

[9] Imron, Ali. 2011. Supervisi Pembelajaran Tingkat Satuan Pendidikan. Jakarta: Bumi Aksara.

[10] Mart, Cagri Tugrul (2013). A Passionate Teacher: Teacher Commitment and Dedication to Student Learning. International Journal of Research ini Progressive Education and Development, Vol.2, No.1. ISSN: 2226-6348.

[11] Mart, Cagri Tugrul (2013). Commitment to School and Student. Intenational Journal of Academic Research in Business and Social Sciences. Vol.3, No.1. ISSN: 2222-6990.

[12] Mulyasa. 2005. Menjadi Guru Frofesional: Menciptakan Pembelajaran Kreatif dan Menyenangkan. Bandung: Remaja Rosdakarya.

[13] Mulyasa. 2007. Standar Kualifikasi dan Kompetensi Guru. Bandung: remaja Rosdakarya.

[14] Muslim, Sri Banun. 2009. Supervisi Pendidikan Meningkatkan Kualitas Profesionalisme guru. Bandung: Alfabeta

[15] Mowday, R. T., Porter, L. W., \& Steers, R. M. (1979). The measurement of organizational commitment. Journal of Vocational Behavior, 14, 224- 247.

[16] Oberholster, F. R. \& Taylor V, J. W. (1999). Spiritual Experience and Organizational Commitment of College Faculty. Unpublished master's thesis, Adventist International Institute of Advanced Studies, Silang, Cavite, Philippines Vol. 2, No. 1, Pp. 57- 78.

[17] Pidarta, Made. 2009. Supervisi Pendidikan Kontekstual. Jakarta: Rineka Cipta.

[18] Purnawanti, Enes, dkk. 2016. Supervisi dalam Peningkatan Kompetensi Melalui Gugus Sekolah. Jurnal Pendidikan: Teori, Penelitian, dan Pengembangan volume I Vol 2 Februari 2016. Halaman 159-164.

[19] Rifma. 2013. Problematika Kompetensi Pedagogik Guru Sekolah Dasar. Pedagogi. 
Jurnal Ilmiah Ilmu Pendidikan volume XIII no. 1 April 2013. 10-17.

[20] Sagala, Syaiful. 2009. Kemampuan Profesional Guru dan Tenaga Kependidikan. Bandung: Alfabeta.

[21] Sahertian, Piet A. 2008. Konsep Dasar dan Teknik Supervisi Pendidikan: dalam Rangka Pembangunan Sumber Daya Manusia. Jakarta: Rineka Cipta.

[22] Saudagar dan Idrus. 2009. Pengembangan Profesionalitas Guru. Jakarta: JP Press.

[23] Singh, K., \& Billinnsgley, B. S. (1998). Professional support and its effects on teachers' commitment. Journal of Educational Research,91(4), 229-239.

[24] Suhardan, Dadang. 2010. Supervisi Profesional: Layanan dalam Meningkatkan Mutu Pembelajaran di Era Otonomi Daerah. Bandung:Alfabeta.
[25] Suprihatiningrum, Jamil. 2012. Guru Profesional: Pedoman Kinerja, Kualifikasi, dan Kompetensi. Jakarta: Ar Ruzz Media.

[26] Sutrisno. 2009. Manajemen Sumber Daya Manusia. Jakarta: Kencana

[27] Wahidah, Siti. 2015. Pelaksanaan Supervisi Pengajaran oleh Kepala Sekolah dalam Meningkitkan kinerja Guru di SMAN 1 banda Aceh. Jurnal Administrasi Pendidikan Pascasarjana Universitas Koala. Volume 3, Nomor 1 Februari 2015. Halaman 126-134.

[28] Yamin dan Maisah.2010. Standarisasi Kinerja Guru. Jakarta: JP Press. Organisasi (Buku 2): Edisi 12. Jakarta: Salemba Empat. 